\title{
Revisiting the Cleavage of Evans Oxazolidinones with $\mathrm{LiOH} / \mathrm{H}_{2} \mathrm{O}_{2}$
}

Gregory L. Beutner, Benjamin M. Cohen, Albert J. DelMonte, Darryl D. Dixon, Kenneth J. Fraunhoffer, Andrew W. Glace, Ehrlic Lo, Jason M. Stevens, Dale Vanyo, Christopher Wilbert.

Chemical and Synthetic Development, Bristol-Myers Squibb Company, One Squibb Drive, New Brunswick, New Jersey 08903, United States.

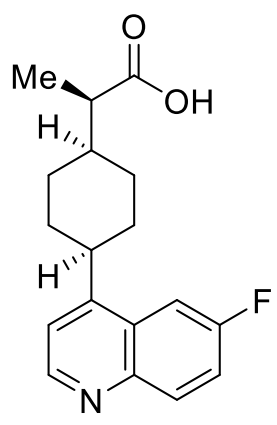

9

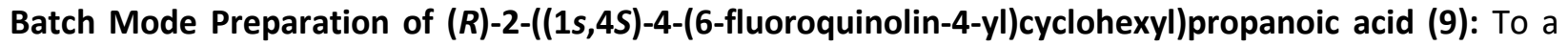
1800-L glass-lined reactor under a nitrogen sweep was charged $254.1 \mathrm{~kg}$ of THF and $57.0 \mathrm{~kg}(127.7 \mathrm{~mol}$, LR) of 8 followed by $127.0 \mathrm{~kg}$ of THF. To the mixture was charged $66.9 \mathrm{~kg}$ (590 mol, $4.6 \mathrm{eq})$ of a $30 \%$ (w/w) solution of hydrogen peroxide in water followed by $2.0 \mathrm{~kg}$ of water. The mixture was heated to $25^{\circ} \mathrm{C}$ and a solution of $8.7 \mathrm{~kg} \mathrm{LiOH}$ monohydrate $(207 \mathrm{~mol}, 1.6 \mathrm{eq})$ in $57.3 \mathrm{~kg}$ of water was charged over 4 hours while maintaining the temperature at $25^{\circ} \mathrm{C}$ and the oxygen content at $<2.5 \%$. To the reactor was charged $9.9 \mathrm{~kg}$ of water and $152.4 \mathrm{~kg}$ of THF. The reaction was held for $3 \mathrm{~h}$. The mixture was cooled to $5{ }^{\circ} \mathrm{C}$ and $73.2 \mathrm{~kg}$ (703 mol, $5.5 \mathrm{eq}$ ) of sodium bisulfite in $171.8 \mathrm{~kg}$ of water was charged slowly while maintaining the temperature at $<30^{\circ} \mathrm{C}$. The mixture was held for 30 minutes with agitation, then held for 30 minutes without agitation. The phases were split and the bottom aqueous layer was discarded. To the mixture was charged $161.0 \mathrm{~kg}$ of $\mathrm{N}, \mathrm{N}$-dimethylacetamide (DMAC) and $48.9 \mathrm{~kg}$ of THF, followed by vacuum distillation at $130 \mathrm{mbar}$ until a temperature of $70^{\circ} \mathrm{C}$ was obtained. To the mixture $26.8 \mathrm{~kg}$ of DMAC was added at $70^{\circ} \mathrm{C}$ followed by $154.6 \mathrm{~kg}$ of water added over 30 minutes. The batch was held at $70{ }^{\circ} \mathrm{C}$ for 1.5 hours and $103.0 \mathrm{~kg}$ of water was added over 30 minutes. The batch was held at $70^{\circ} \mathrm{C}$ for 1.5 hours. The mixture was cooled to $20^{\circ} \mathrm{C}$ over 6 hours and held for 60 hours. The slurry was filtered and washed with twice with $167 \mathrm{~kg}$ of 1:1 DMAC:Water. The cake was washed two times with $162 \mathrm{~kg}$ of 1:3 acetonitrile:water and dried at $50{ }^{\circ} \mathrm{C}$ under vacuum to afford $35.0 \mathrm{~kg}$ of 9 as a white solid (91.1\% yield). ${ }^{1} \mathrm{H}$ NMR $\left(600 \mathrm{MHz}, \mathrm{DMSO}-\mathrm{d}_{6}\right) \delta 12.09(\mathrm{~s}, 1 \mathrm{H}), 8.80(\mathrm{~d}, J=4.5 \mathrm{~Hz}, 1 \mathrm{H}), 8.06$ (dd, J = 9.2, 5.8 Hz, 1H), 7.91 (dd, J $=10.9,2.8 \mathrm{~Hz}, 1 \mathrm{H}), 7.61(\mathrm{ddd}, J=9.1,8.2,2.8 \mathrm{~Hz}, 1 \mathrm{H}), 7.45(\mathrm{~d}, J=4.5 \mathrm{~Hz}, 1 \mathrm{H}), 3.41-3.27(\mathrm{~m}, 1 \mathrm{H}), 2.72-2.63$ (m, 1H), 1.86-1.61 (m, 9H), $1.08(\mathrm{~d}, J=6.8 \mathrm{~Hz}, 3 \mathrm{H}) ;{ }^{13} \mathrm{C}$ NMR (150 MHz, DMSO-d 6 ) $\delta 177.7,159.9,152.2$, $149.8,145.1$, 132.6, 127.2, 118.9, 118.7, 107.1, 39.1, 37.2, 35.7, 28.7, 27.8, 27.2, 26.2, 15.6; HRMS (ESI) calculated for $\mathrm{C}_{18} \mathrm{H}_{21} \mathrm{FNO}_{2}[\mathrm{M}+\mathrm{H}]^{+}: 302.1551$, found 302.1563 . 

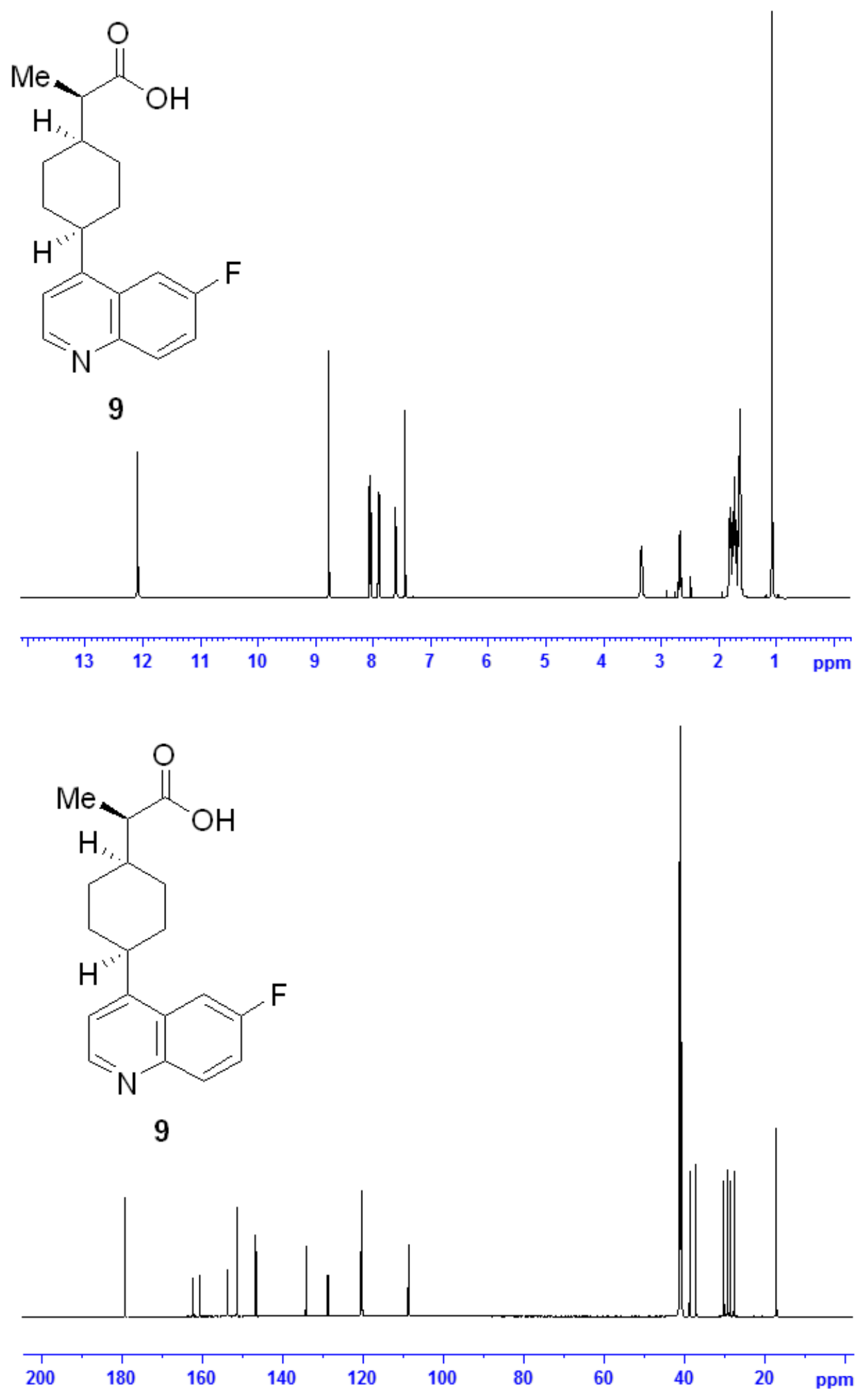


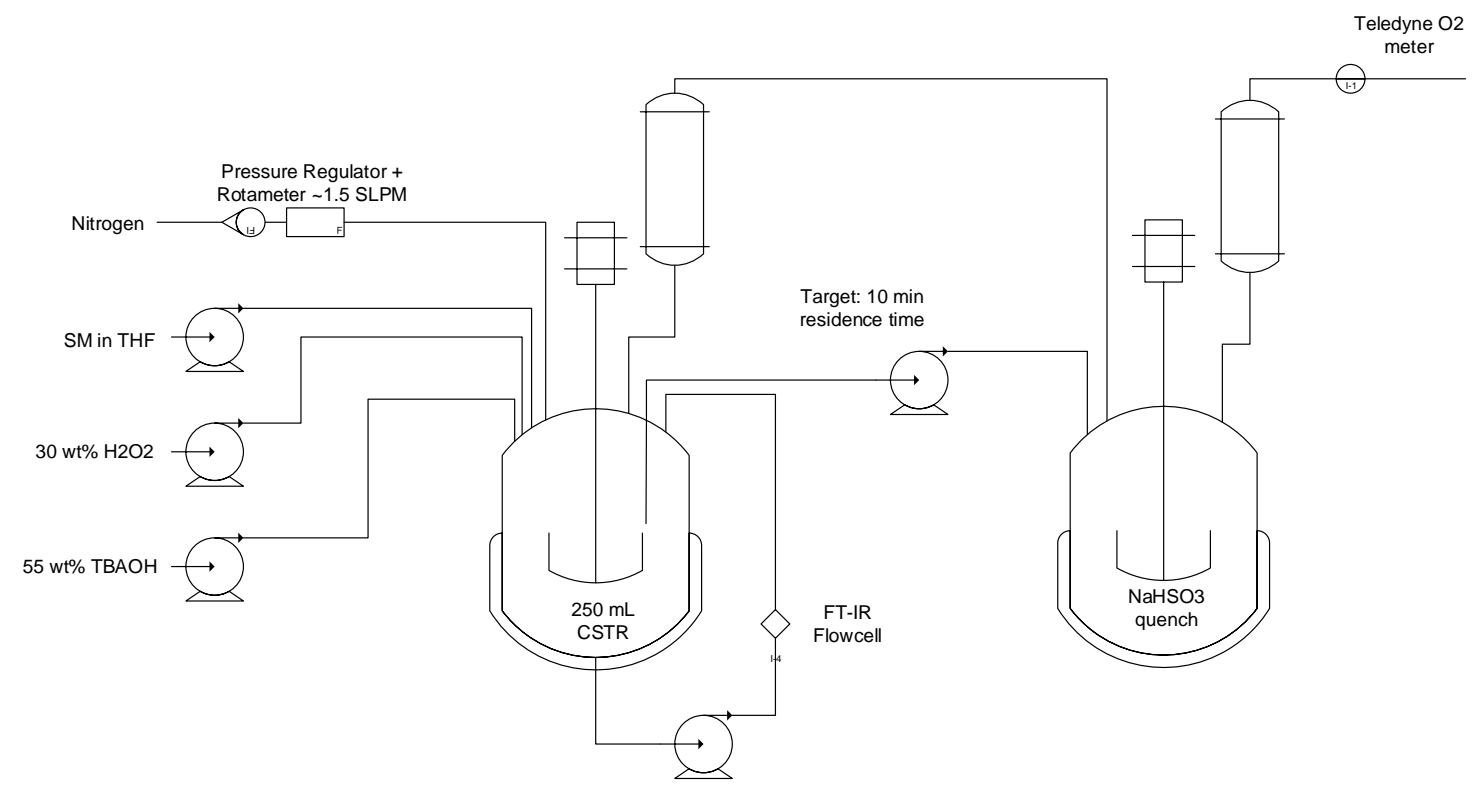

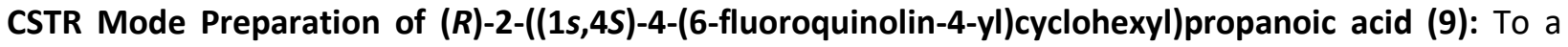
250- $\mathrm{mL}$ reactor under $\mathrm{N}_{2}$ sweep was added $50 \mathrm{~mL}$ THF. This reactor was connected to a second 1-L reactor containing $30 \mathrm{~g}$ sodium bisulfite $(288.9 \mathrm{mmol})$ dissolved in $60 \mathrm{~mL}$ water via a teflon line with a diaphragm pump. The base of the Teflon line was maintained at $100 \mathrm{~mL}$ volume mark of the $250 \mathrm{~mL}$ reactor to maintain a $20 \mathrm{~mL}$ residence time. Three HPLC pumps were then used to charge reagent solutions to the $250 \mathrm{~mL}$ reactor. Pump 1 delivered hydrogen peroxide ( $30 \mathrm{wt} \% \mathrm{H}_{2} \mathrm{O}, 145.6 \mathrm{mmol}, 6.5$ equiv, $0.26 \mathrm{~mL} / \mathrm{min}$ ). Pump 2 delivered a solution of $10.0 \mathrm{~g}$ of 8 in $100 \mathrm{~mL}$ THF $(22.40 \mathrm{mmol}, 2.0 \mathrm{~mL} / \mathrm{min})$. Pump 3 delivered tetrabutylammonium hydroxide solution ( $55 \mathrm{wt} \% \mathrm{H}_{2} \mathrm{O}, 35.83 \mathrm{mmol}, 1.6$ equiv, $0.30 \mathrm{~mL} / \mathrm{min}$ ). Pumps were started sequentially and allowed to run for $60 \mathrm{~min}$ before starting diaphragm pump to remove reaction mixture to 1-L quench tank. Assay of the final quenched reaction mixture at the end of addition showed $>99 \%$ conversion and $80 \%$ in-process yield. The lower aqueous layer was then removed and $35 \mathrm{~mL}$ DMAC was added. The solution was then distilled at $50 \mathrm{mmHg}$ with a $40^{\circ} \mathrm{C}$ jacket to remove the bulk of the THF. The solution was then heated to $70^{\circ} \mathrm{C}$ for slow addition of $28 \mathrm{~mL}$ water. Upon completion of the addition a suspension had formed and the mixture was cooled to $20^{\circ} \mathrm{C}$. An additional $18 \mathrm{~mL}$ of water was added and the resulting slurry aged for $1 \mathrm{~h}$ at $20{ }^{\circ} \mathrm{C}$. The suspension was filtered, washed with $30 \mathrm{~mL} 1: 1$ DMAC:water and dried under $\mathrm{N}_{2}$ /vacuum sweep to obtain $4.8 \mathrm{~g}$ of 9 as a white solid (68\% yield). Final solids contained 1.0 AP of hydroxyamide 10. 
<smiles>C[C@H]1C[C@H](c2ccnc3ccc(F)cc23)CCC1[C@H](C)C(=O)NC(CO)c1ccccc1</smiles>

10

(R)-2-((1s,4S)-4-(6-fluoroquinolin-4-yl)cyclohexyl)-N-((R)-2-hydroxy-1-phenylethyl)propanamide (10): To a 4-neck flask were charged $10.0 \mathrm{~g} 8(22.40 \mathrm{mmol}, \mathrm{LR}), 20 \mathrm{~mL}$ water and $80 \mathrm{~mL}$ THF. The mixture was cooled to $0^{\circ} \mathrm{C}$ for addition of a solution of $2.8 \mathrm{~g} \mathrm{LiOH}-\mathrm{H}_{2} \mathrm{O}\left(67.2 \mathrm{mmol}, 3.0\right.$ eq.) in $25 \mathrm{~mL} \mathrm{H} \mathrm{H}_{2}$ over $60 \mathrm{~min}$ before warming to $20-25^{\circ} \mathrm{C}$. The reaction mixture was stirred until 8 was consumed. Added $50 \mathrm{~mL}$ brine, extracted twice with $50 \mathrm{~mL}$ EtOAc then dried combined organic phases over $\mathrm{MgSO}_{4}$. Concentrated to a low volume, filtered and washed solids with $20 \mathrm{~mL} \mathrm{DCM}$ to afford $5.0 \mathrm{~g}$ of 10 as a white solid (53\% yield). ${ }^{1} \mathrm{H} \mathrm{NMR}\left(401 \mathrm{MHz}, \mathrm{CD}_{3} \mathrm{OD}\right) \delta 8.87(\mathrm{~d}, J=4.5 \mathrm{~Hz}, 1 \mathrm{H}), 8.25(\mathrm{~d}, J=8.2 \mathrm{~Hz}, 1 \mathrm{H}), 8.10(\mathrm{dd}, J=9.2,5.8 \mathrm{~Hz}, 1 \mathrm{H})$, 7.97 (dd, $J=11.0,2.7 \mathrm{~Hz}, 1 \mathrm{H}), 7.67(\mathrm{td}, J=8.8,2.7 \mathrm{~Hz}, 1 \mathrm{H}), 7.56(\mathrm{~d}, J=4.6 \mathrm{~Hz}, 1 \mathrm{H}), 7.34(\mathrm{~d}, J=4.4 \mathrm{~Hz}, 4 \mathrm{H})$, $7.24(\mathrm{dq}, J=8.6,4.1 \mathrm{~Hz}, 1 \mathrm{H}), 4.91(\mathrm{dd}, J=14.5,6.6 \mathrm{~Hz}, 1 \mathrm{H}), 4.81(\mathrm{t}, J=5.0 \mathrm{~Hz}, 1 \mathrm{H}), 3.62-3.51(\mathrm{~m}, 2 \mathrm{H})$, $3.42-3.31(\mathrm{~m}, 1 \mathrm{H}), 2.80(\mathrm{dq}, J=13.5,6.7 \mathrm{~Hz}, 1 \mathrm{H}), 2.05-1.90(\mathrm{~m}, 1 \mathrm{H}), 1.90-1.58(\mathrm{~m}, 8 \mathrm{H}), 1.00(\mathrm{~d}, J=6.6$ $\mathrm{Hz}, 3 \mathrm{H}) .{ }^{13} \mathrm{C}$ NMR (101 MHz, DMSO) $\delta 180.2,164.9$ (d, $\left.J=244.6 \mathrm{~Hz}\right), 157.6$ (d, $\left.J=5.6 \mathrm{~Hz}\right), 154.7,150.2$, $146.4,137.6$ (d, $J=9.4 \mathrm{~Hz}$ ), 133.0, $132.2(\mathrm{~d}, J=9.4 \mathrm{~Hz}), 131.9,131.6,124.0$ (d, J = 25.7 Hz), 123.7, 112.2 (d, $J=22.5 \mathrm{~Hz}$ ), 69.6, 59.4, 42.6, 40.4, 33.4, 32.6, 32.4, 31.4, 21.1. HRMS (ESI) Calcd. for $\left[\mathrm{C}_{26} \mathrm{H}_{30} \mathrm{FN}_{2} \mathrm{O}_{2}{ }^{+}\right]$ $\left([\mathrm{M}+\mathrm{H}]^{+}\right):$421.2286, found: 421.2285. IR: 3282, 3059, 2929, 2859, 1631, 1514, 1453, 1217, 1169, 1070, $854,830,722,700,523,431 \mathrm{~cm}^{-1}$

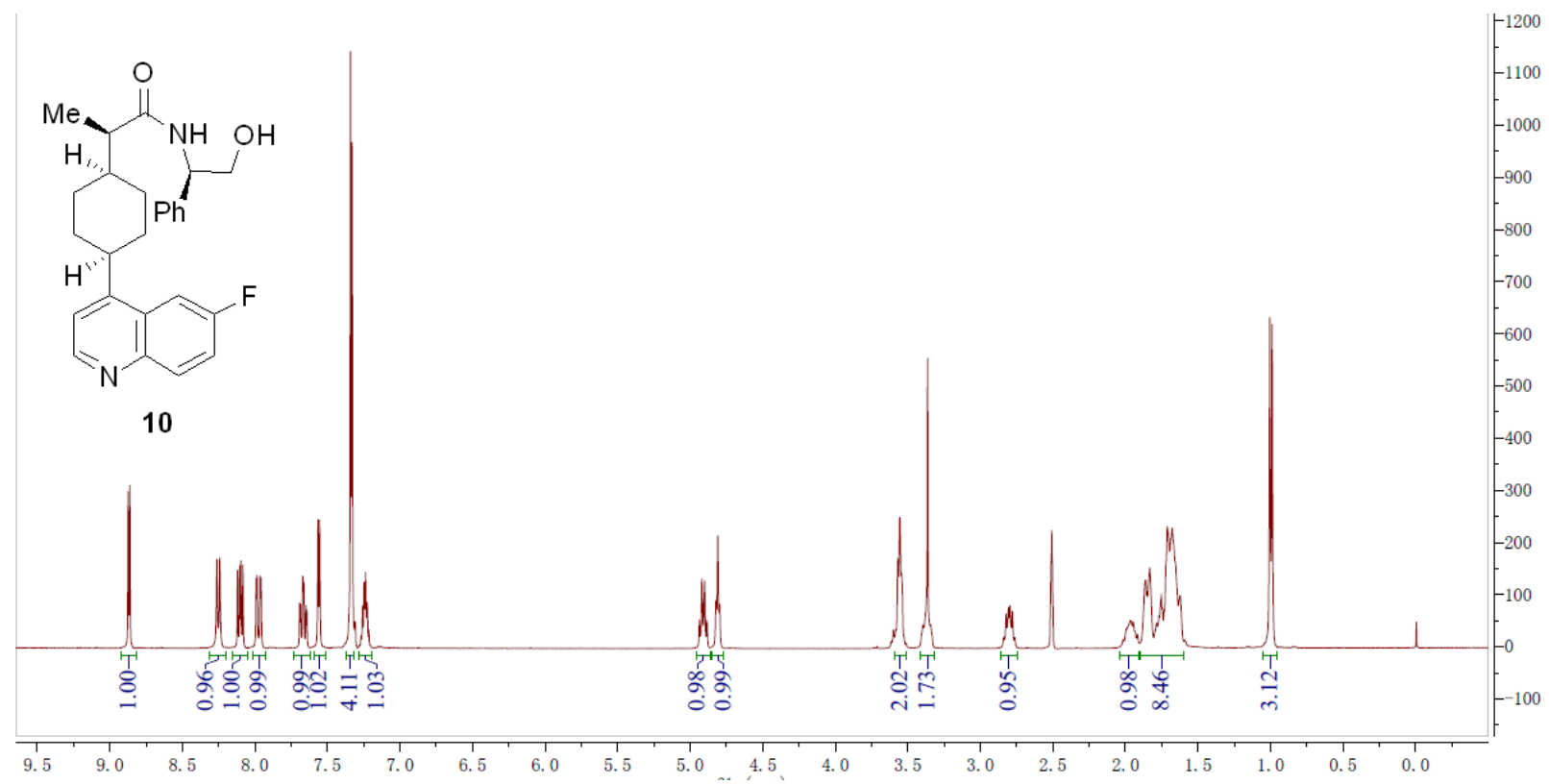




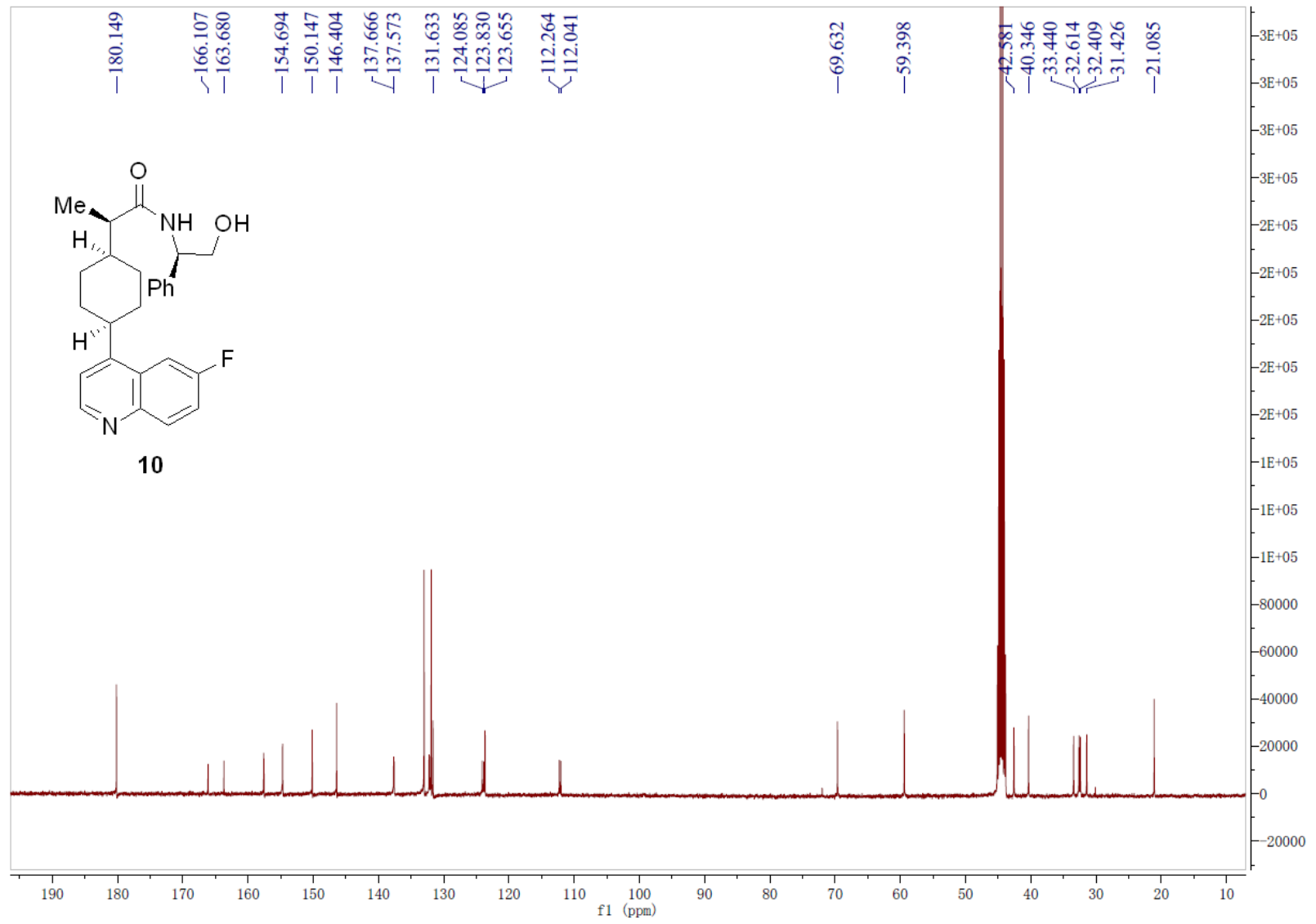

